\title{
Clinical potentials of human pluripotent stem cells in lung diseases
}

\author{
Yuan Quan and Dachun Wang*
}

\begin{abstract}
Lung possesses very limited regenerative capacity. Failure to maintain homeostasis of lung epithelial cell populations has been implicated in the development of many life-threatening pulmonary diseases leading to substantial morbidity and mortality worldwide, and currently there is no known cure for these end-stage pulmonary diseases. Embryonic stem cells (ESCs) and somatic cell-derived induced pluripotent stem cells (iPSCs) possess unlimited self-renewal capacity and great potential to differentiate to various cell types of three embryonic germ layers (ectodermal, mesodermal, and endodermal). Therapeutic use of human ESC/iPSC-derived lung progenitor cells for regeneration of injured or diseased lungs will have an enormous clinical impact. This article provides an overview of recent advances in research on pluripotent stem cells in lung tissue regeneration and discusses technical challenges that must be overcome for their clinical applications in the future.
\end{abstract}

Keywords: Induced pluripotent stem cells; Embryonic stem cells; Differentiation and characterization; Lung stem/progenitor cells; and Lung tissue engineering

\section{Introduction}

Pulmonary diseases are one leading cause of morbidity and mortality worldwide. Currently available treatments can only alleviate symptoms or delay disease progression within a limited time range for patients with end-stage pulmonary diseases. Lung transplantation remains the only definitive treatment for many end-stage patients, yet its clinical impact is limited by shortage of suitable donor lungs and transplant rejection. More than 10\% patients on waiting list die each year before transplantation [1], and the 5-year survival rate of recipients is only approximately $50 \%$ [2,3]. Recent findings in stem cell research have attracted a lot of interest to developing reliable means to regenerate injured/diseased lungs. Studies on animal lung injury models have shown that there are divergent progenitor populations responsible for maintaining homeostasis of lung epithelia in anatomically different regions. However, technical difficulty to isolate and characterize these progenitor types due to the complex lung structure continues to hinder the understanding of the role of endogenous regenerative pathways in lung tissue maintenance

\footnotetext{
* Correspondence: dachun.wang@uth.tmc.edu

The Brown Foundation Institute of Molecular Medicine for the prevention of Human Diseases, University of Texas Medical School at Houston, 1825 Pressler Street/IMM 437D, Houston, TX 77030, USA
}

and repair in response to injuries. During the past several years, significant progress has been made in purification and characterization of lung progenitor cells derived from embryonic stem cells (ESCs) and induced pluripotent stem cells (iPSCs). These ESC/iPSC-derived lung progenitor cells hold great promise for understanding lung stem cell biology and disease processes, developing cell-based therapies for incurable pulmonary diseases, and generating bioengineered lungs. This review will summarize current advances in lung stem cell research and discuss technical challenges for possible therapeutic use of pluripotent stem cells in lung tissue regeneration in the future.

\section{Review}

Pulmonary epithelia and stem/progenitor cell types

The lung is a complex organ composed of anatomically different regions including trachea, bronchi, bronchioles and alveoli, each lined with functionally and structurally distinct epithelium. The pseudostratified epithelium covering trachea and bronchi is composed predominantly of basal, mucous secretory goblet cells and ciliated cells, along with a few discrete pulmonary neuroendocrine cells. In bronchioles, especially in the respiratory bronchioles, non-ciliated secretory Clara cells cover most of the surface area, although the less frequent ciliated cells also reside in

\section{实}


this domain. The relative abundance of Clara cells in the transitional zone between large airways and alveoli imply that they may play an important role in coordinating the functions of the conducting airways and the gasexchanging region. The alveolar epithelium covers more than $99 \%$ of the internal surface area of the lung and is composed of the alveolar epithelial type I cells (ATICs) and type II cells (ATIICs). ATICs are large and flat, covering about $95 \%$ of the gas-exchanging alveoli; together with endothelium of surrounding capillaries, they form a very thin blood-air interface essential for $\mathrm{O}_{2} / \mathrm{CO}_{2}$ exchange. In contrast, ATIICs are small, cuboidal cells, and play an important role in maintenance of alveolar homeostasis.

As pulmonary epithelia are constantly exposed to injurious stimuli from the environment, the lung needs to generate new cells to replenish injured and aged epithelial cells for maintaining normal structure and function. It is known that the endogenous repair capacity of the lung is relative low [4-7] and may fail after repeated challenges, leading to development of life-threatening pulmonary diseases such as asthma, chronic obstructive pulmonary disease, and idiopathic pulmonary fibrosis. Due to lung structural complexity with cellular diversity and slow epithelial cell turnover rates, it is still a challenge to isolate and characterize lung stem/progenitor cells for exploring the lung disease processes and endogenous repair mechanisms. To date, whether there are undifferentiated multipotent stem cells with the ability to self-renew indefinitely in lung is controversial. Injuries to mobilize stem cells for tracking DNA label-retaining cells (LRCs) are a key approach to identifying stem/progenitor cell compartment in distinct lung regions. There is mounting evidence showing that local progenitor cells function to renew injured and aged epithelial cells in anatomically different regions [8-11]. In the trachea and larger airways, basal cells have traditionally been considered as progenitor cells, with the capacity for proliferating and differentiating into basal, ciliated, and goblet cells $[12,13]$. In human, the large airway epithelium is more pseudostratified, and there are parabasal cells located right above the basal cells. Because parabasal cells express high level of proliferation marker MIB-1, they are thought to function as transient amplifying (TA) cells derived from basal cells in the larger airways $[14,15]$. In addition, subcutaneous transplantation experiments have shown that tracheal grandular cells can repopulate tracheal epithelium. In $\mathrm{SO}_{2}$-induced tracheal injury model of mice, LRCs accumulated in submucosal gland ducts lasted longer than those in tracheal epithelium $[16,17]$, suggesting that submucosal gland ducts may harbor relatively primitive precursor cells for tracheal epithelium.

In distal lung, injury studies using naphthalene, a Clara cell-specific toxic agent, to deplete Clara cells have revealed that two populations of progenitor cells are responsible for the maintenance of bronchiolar epithelium: the abundant facultative TA Clara cells, and a subset of variant Clara cells that is cytochrome P450 2 F2 negative and stem cell antigen positive [18-22]. These variant Clara cells are naphthalene-resistant and express Clara cell-specific marker CCSP. They reside in discrete groups at the bronchioalveolar duct junction (BADJ) and the branch point-associated neuroepithelial bodies. It has been demonstrated that the variant Clara cells located at BADJ also express ATIIC-specific surfactant protein C (SPC) [23,24]. These cells appear to possess the ability to proliferate and differentiate into both bronchiolar and alveolar epithelial cells in vitro, and may be important in the maintenance of both bronchiolar and alveolar epithelial cell populations [23]. Studies using mouse injury model have shown that ATIICs possess proliferative capacity and play an important role during the re-epithelialization of alveoli after lung injury. In addition, multipotent stem cells with the potential of generating distal lung-like tissue in vivo have been isolated from adult lungs of sheep and rats [25]. More recently, undifferentiated human lung stem cells (hLSCs) were identified in distal lungs. These cells are antigen c-kit ${ }^{+}$and have the capacity to generate human bronchioles, alveoli and pulmonary vessels after injected into injured mouse lungs [26]. These studies provide strong evidence for the existence of distal lung stem cells, yet their relationship with Clara and ATIICs is still unclear.

\section{Lung epithelial progenitor cells derived from ESCs Strategies to derive ESCs into lung epithelial progenitor cells}

The ESCs isolated from the inner cell mass of blastocyststage embryos are undifferentiated, pluripotent cells $[27,28]$, and can be induced to differentiate in vitro into a wide range of different cell types [29-36]. ESC-derived lung stem/progenitor cells are a promising cell source for exploring therapeutic methods treating lung injuries and pulmonary genetic disorders. Due to the fact that most lung stem/progenitor cell types as well as their hierarchy have not been well characterized, progress in development of procedures to derive ESCs into lung stem/progenitor cells has been slow, and the mechanisms underlying the differentiation of ESCs into large lung airway epithelial cells remains elusive. It has been demonstrated that ESCs can be differentiated into Clara cells $[37,38]$ and ATIICs via embryonic body (EB) formation or co-culture with pulmonary mesenchyme [39-41]. However, these spontaneous differentiation procedures are not efficient, generating only a very small percentage of ESC-derived lung cells [42]. Recently, procedures to enrich definitive endoderm for effective differentiation of ESCs into ATIICs have been developed by using a growth factor cocktail or a lungspecific cell-conditioned medium [43], but are not yet successful in generating a homogenous population of 
ATIICs. In these published studies, the derivation of ATIICs from ESCs was demonstrated by ATIIC-specific SPC expression and morphological appearance of lamellar bodies. It remains unclear whether these ESC-derived ATIICs possess normal biological function. In addition, these differentiated cultures generate a mixed population of cell derivatives and may contain the remaining pluripotent cells, which is not suitable for transplantation because they carry a significant risk of producing teratomas after transplantation in vivo.

In order to obtain transplantable ESC-derived ATIICs, our laboratory has developed a reliable procedure to generate stably transfected human ESC (hESC) lines containing a single copy of ATIIC-specific SPC promoter/neomycin ${ }^{\mathrm{R}}$ $\left(\mathrm{NEO}^{\mathrm{R}}\right)$ transgene [44]. As SPC is specifically expressed by ATIICs, only hESC-derived ATIICs can express $\mathrm{NEO}^{\mathrm{R}}$ and survive in G418 selected cultures. Without the need of EB formation, these hESC lines can be selectively differentiated into an essentially pure population of ATIICs (hES-ATIICs) when cultured on matrigel coated dishes in the presence of G418. These hES-ATIICs show the biological features and morphological characteristics of normal ATIICs, including lamellar body formation, expression of surfactant proteins, and the ability to proliferate and differentiate into ATICs in vitro. Hence, they can serve as a transplantable source of ATIICs for the exploration of their possible clinical application in the future [45].

\section{Characterization of ESC-derived ATIICs in vivo}

Bleomycin (BLM)-induced alveolar injury is well characterized in mice $[46,47]$, and has been used as a model to test therapeutic potential of hES-ATIICs [45]. When transplanted into SCID mice on day 1 or 2 after exposure to BLM, a substantial number of hES-ATIICs remained in the injured lungs; approximately $34 \%$ of these expressed ATIC markers on day 10 after BLM challenge, suggesting that these transplanted hES-ATIICs had differentiated into ATICs in vivo [45]. Lung injury was abrogated in mice transplanted with hES-ATIICs, demonstrated by significantly decreased collagen deposition and complete recovery of body weight and arterial blood oxygen levels. It was also noted that numerous endogenous mouse ATIICs survived in the BLM-injured lungs of hES-ATIIC transplanted mice, but not in BLM-injured lungs receiving monocytes or normal saline, suggesting that structurally engrafted hES-ATIICs may provide an appropriate signal microenvironment via their paracrine effect in activating endogenous repair. Thus, structural engraftment and differentiation of hES-ATIICs coupled with activated endogenous ATIICs can lead to robust re-epithelialization of injured alveoli. Further investigations are needed to characterize the signaling communication between ATIICs for maintaining alveolar homeostasis. We also found that BLM-injured mice transplanted with hES-ATIICs survived as normal mice without experiencing tumorigenic side effects, demonstrating that genetic selection is an effective approach to generating transplantable ESC-derived lung stem/progenitor cells. However, random transgene insertion into the chromosomal DNA may cause unpredicted critical gene dysfunction. In addition, only approximately $5 \%$ hES-ATIICs remained in the BLM-injured lungs 10 months after transplantation. Poor long-term retention/ survival of engrafted hES-ATIICs in injured lungs of SCID mice [45] indicates that the mouse lung may reject hES-ATIICs or fail to provide an appropriate microenvironment for hES-ATIICs to rebuild the progenitor cell pools after injury. Therefore, mouse ESCs (mESCs) should be used instead to explore the potential long-term therapeutic benefit of ESC-derived ATIICs in mice injury models. More recently, our laboratory has generated genetically modified $\mathrm{mESC}$ lines harboring a single copy of ATIIC-specific $\mathrm{NEO}^{\mathrm{R}}$ transgene in Rosa 26 gene locus [48]. These random genetic insertion-free $\mathrm{mESC}$ lines can be directed to differentiate into a homogenous population of functional ATIICs, providing a reliable source of cells for further characterization of ESC-derived ATIICs in mice lung injury models.

\section{Lung epithelial progenitor cells derived from iPSCs}

The methodology for reprogramming of somatic cells into iPSCs with defined reprogramming factors (Oct4, Sox2, $c M y c$ and Klf4) was established by Yamanaka's group in 2006 [49]. As renewable source of autologous, diseasespecific cells, iPSCs hold great promise in regenerative medicine for modeling diseases, screening drugs and developing cell-based therapeutic strategies. Initially, the technique uses retrovirus or lentivirus to deliver necessary reprogramming factors for successfully reprogramming [49-51]. However, as random integration of multiple copies of each transgene to over-express reprogramming factors for reprogramming is a stochastic process, the generated iPSC lines exhibit considerable phenotypic variation and may have unpredictable critical gene dysfunction. In addition, constant expression of reprogramming transgenes may result in deleterious outcomes in which the derived iPSCs could develop into tumor or lose their pluripotency. For safety improvement, many alternative techniques have been developed by using non-integrating vectors [52-55] or PiggyBac transposon system [56] to avoid or eliminate insertional mutagenesis, yet the application of these methods is limited by the impractically low reprogramming efficiency. Recently, iPSCs have been generated by direct delivery of recombinant proteins, RNAs, or microRNAs [57-59]. These nongenetic techniques allow generating genetic integration-free iPSCs, yet they require special expertise for preparing proteins, RNA and mature microRNA and need multiple times of transduction/transfection for reprogramming, and the reprogramming process is 
still stochastic with low reprogramming efficiency. Even though efficient generation of genetic integration-free and exogenous reprogramming-factor-free iPSCs continues to be a challenge, a series of animal studies have demonstrated the potential clinical value of iPSC-derived progenitor cells in treatment of congenital hypomyelination, spinal cord injury, diabetes, and Parkinson's disease [60-63]. Recently, human lung disease-specific iPSC lines associated with either cystic fibrosis or alpha-1 antitrypsin deficiency-related emphysema have been generated with a single excisable lentiviral vector [64]. Although the derived iPSC lines could be useful for lung disease modeling, the use of a viral vector for reprogramming and the part of DNA sequence left behind at unknown site(s) after removal of transgenes are potential drawbacks. In addition, difficulty to obtain iPSC derived transplantable cell types is still a major obstacle to developing clinical application of iPSCs.

In order to generate random-insertion-free and exogenous reprogramming-factor-free hiPSCs that can be selectively differentiated into pure populations of ATIICs without the need of any additional treatment or genetic modification, our laboratory developed a single sitespecific targeting vector, which harbors the reprogramming transgenes controlled by Tet-On inducible gene expression system, ATIIC-specific $\mathrm{NEO}^{\mathrm{R}}$ transgene, and loxP targeting sequence [65]. With this non-viral targeting vector, all required transgenes can be inserted into a site immediately downstream of $\beta$-2-microglobulin (B2M) gene locus without causing B2M dysfunction. The reprogramming transgenes can be induced to express for efficient reprogramming of human skin fibroblast, and subsequently removed to obtain genetic integration-free and exogenous reprogramming-factor-free hiPSC lines. Because the derived hiPSCs contain the ATIIC-specific $\mathrm{NEO}^{\mathrm{R}}$ transgene, they can be selectively differentiated into an essentially pure population of functional ATIICs after cultured on matrigel-coated dishes in differentiation medium (DM) with $20 \mu \mathrm{g} / \mathrm{ml}$ of G418 for 14 days [65]. The selective differentiation procedure for generation of hiPSC-derived ATIICs is illustrated in Figure 1. The $\mathrm{SPC}^{+}$cells can be enriched as early as on day 10. It was found that these early derived $\mathrm{SPC}^{+}$cells did not express surfactant protein A (SPA) and B (SPB), but possessed robustly proliferative capacity, suggesting that they may be early primitive progenitor cell type(s). On day 14, the hiPSC-derived $\mathrm{SPC}^{+}$cells (hiPSC-ATIICs), which did not express CCSP, expressed thyroid transcription factor one (TTF1) and surfactant proteins with typical ultra-structure of ATIICs (Figure 2). We showed that these hiPSC-ATIICs possess regulatable capacity for synthesizing and secreting surfactant proteins and lipids as primary human ATIICs. Like hES-ATIICs discussed above, the hiPSC-ATIICs have great potentials in engrafting and differentiating into
ATICs in vivo for re-population of BLM-injured alveoli and repair of damaged pulmonary function. This is a one-step site-specific genetic modification. This novel strategy makes it possible for the first time to generate lung disease-specific hiPSC-ATIICs for exploring their clinical application and modeling alveolar diseases.

\section{Lung tissue bioengineering}

Proof-of-principle studies in tissue engineering have strongly demonstrated the potential of engineered functional organs such as heart, liver and kidney [66-68]. Generation of engineered lungs is an attractive prospect for the treatment of end-stage pulmonary diseases. Several groups have been able to culture fetal and adult lung cells in three-dimensional culture systems with synthetic scaffolds for creating engineered lung tissue ex vivo [69-73]. While the natural and synthetic scaffolds are capable of supporting differentiation of ESCs into $\mathrm{CCSP}^{+}$and $\mathrm{SPC}^{+}$ cells, it is not clear whether these cells are functional distal airway and alveolar cell types. The published data have shown the potential of Gelfoam sponge scaffold seeded with fetal rat lung cells in forming alveolus-like structure in vivo [73]. However, whether the engineered tissue is capable of ventilation-perfusion for gas exchange remains to be investigated.

Recently, substantial advances have been made in engineering functional trachea using an artificial matrix and a decellularized, cadaveric scaffold [74,75]. Macchiarini et al. developed a tissue-engineering procedure to generate a trachea by seeding recipient's airway epithelial cells and chondrocytes onto a decellularized, cadaveric trachea scaffold within a custom bioreactor. The engineered airway segment was then used to replace the left main bronchus with malacia to restore the end-staged patient's pulmonary function without the need of immunosuppressive drugs. The 5-year follow-up results showed that the patient had a normal life, suggesting that the tissue-engineering strategy is safe and promising in generating engineered trachea for autologous transplantation [76].

It is intrinsically difficult to decellularize and recellularize whole lung tissue to recapitulate its complex structure. Despite this, significant progresses have also been made in using a whole decellularized lung as a scaffold to generate engineered lung $[77,78]$. The fully decellularized lung retains its native architecture with acellular vasculature, airways and alveoli, and appears superior to other simple bioartificial scaffolds to support differentiation and recellularization of pluripotent stem cells. The cultured lung epithelial and vascular endothelial cells in the decellularized lung scaffold can efficiently repopulate the epithelial and vascular structures in a custom bioreactor to generate engineered lung with the potential for ventilation and gas exchange in vivo. However, due to the fact that some of decellularized areas are not completely recellularized to 


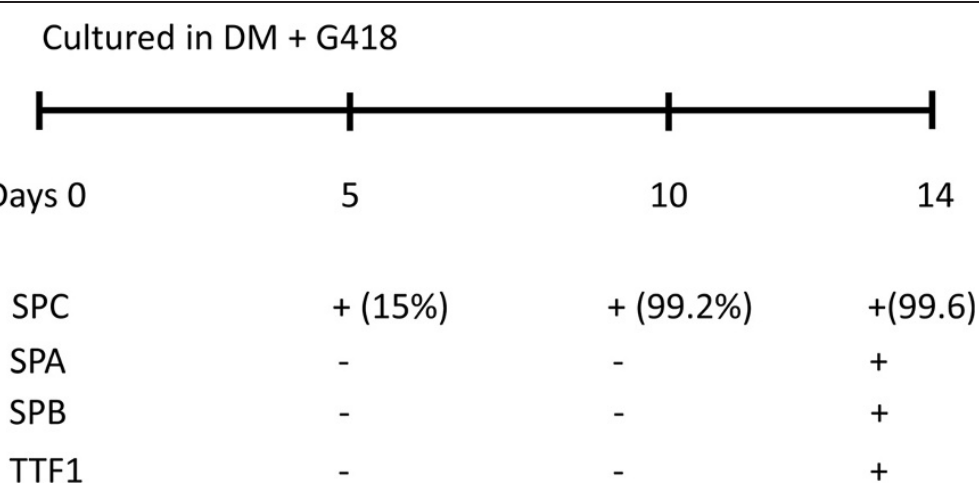

Figure 1 Diagram of hiPSC differentiation. The hiPSCs were cultured on matrigel-coated plates in DM containing $20 \mu \mathrm{g} / \mathrm{ml}$ of G418 for 14 days. The SPC positive cells were observed in the differentiating cultures at a very early time point (day 5), and can be enriched into a homogenous population (>99\%) with robust proliferation capacity on day 10. The hiPSC-derived ATIICs were observed in the cultures on day 14 , which expressed TTF1 and surfactant proteins (SPA, SPB, and SPC).

reconstitute the alveolar-capillary barrier, there are red blood cells and thrombus formations in the airspaces of engineered lungs after transplantation. Although the engineered lungs participate gas exchange in vivo for only short time intervals, these significant advances demonstrate the feasibility of using whole decellularized, cadaveric lungs as scaffolds for generation of functionally engineered lungs for transplantation.

Using patient-derived iPSCs to recellularize the decellularized, cadaveric lung scaffolds that lack donor cells expressing alloantigens is expected to generate functionally engineered lungs for "autologous" transplantation. Like ESCs, iPSCs have the potential to differentiate into many different tissue cell types. Thus, preventing nonspecific differentiation and overgrowth of iPSCs will be a challenge for generating engineered lungs. Recently, the relatively primitive $c-k i t^{+} h L S C s$ have been identified. The c-kit ${ }^{+} h L S C s$ are lung-specific and have the capacity for generating distal lung structure, including bronchioles, alveoli and blood vessels in vivo [26]. Although the ability of c-kit ${ }^{+} h L S C s$ to generate larger airway still remains to be investigated, hiPSC-derived c-kit ${ }^{+}$hLSCs is considered a promising source of cells that can be used to recellularize the decellularized lung scaffold. Developing a strategy to direct differentiation of patient-derived iPSCs into the more primitive c-kit ${ }^{+} \mathrm{hLSCs}$ that can be used to recellularize the decellularized lung scaffold to reconstitute its complex structure with orchestrated and coordinated epithelia and endothelium is an attractive prospect.

\section{Conclusion}

Potential application of lung stem/progenitor cell types derived from iPSCs and ESCs holds great promise in modeling pulmonary diseases and developing cell-based therapies for treatment of severe lung diseases. Because ESCs and their derivatives express alloantigens, including MHC class I molecules that are primary targets for immune rejection by self-recognizing $\mathrm{T}$ cells, development of

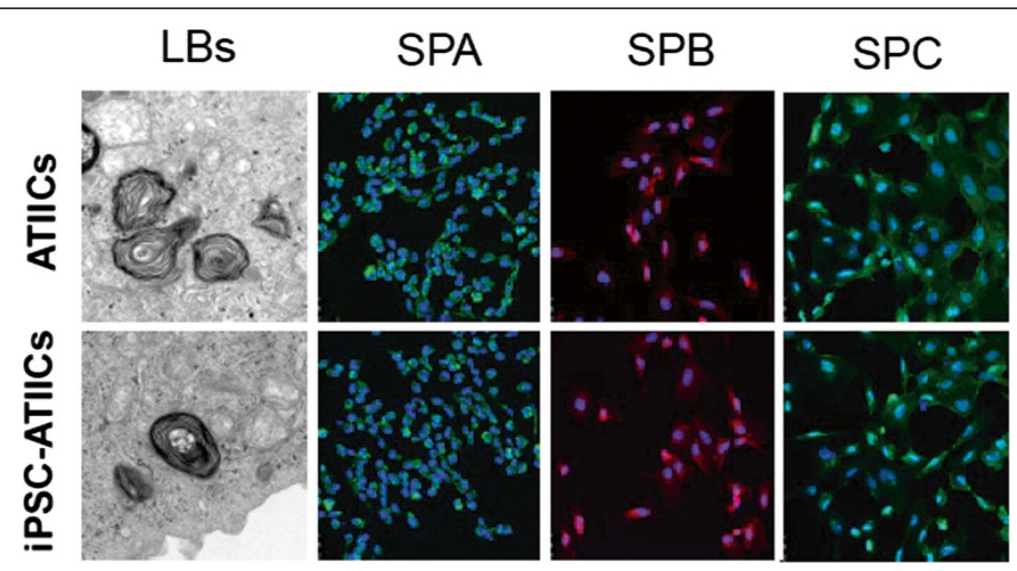

Figure 2 Electron micrographs showed well-developed lamellar bodies (LBs) in G418-selected hiPSC-ATIICs, as in the control human ATIICs; the immunofluorescent staining images demonstrated that G418-selected hiPSC-ATIICs expressed SPA, SPB and SPC as control human ATIICs did. 
immune rejection towards grafted ESC derivatives is a major limitation to their clinical application. Patientderived iPSCs are conceivably genetically identical to the patient. However, reprogramming may result in a number of abnormal gene expressions in iPSC-derived cells, causing immune rejection in the syngeneic recipients as reported by Zhao et al. [79]. Technologies for generating iPSCs need to be further improved in order to obtain "clinical grade" iPSCs. Whether the novel strategy that we have developed to generate the genetic integrationfree and exogenous reprogramming factor-free hiPSC lines may cause abnormal gene expression or defects needs to be further evaluated. As ESCs are reliable and versatile for generating many different tissue cell types, it is an appealing option to generate a "universal" hESC line with significantly reduced expression of MHC molecules. It is hoped that lung stem/progenitor cells derived from a "universal" hESC line can be transplanted without evoking robust immune response from HLA class I mismatched recipients, and thus can be used to generate engineered lungs for clinical use in the future.

\section{Competing interests}

The authors have no financial conflict of interests to declare.

\section{Authors' contributions}

YQ and DW contributed equally to the literature review and manuscript preparation. Both authors read and approved the final manuscript.

\section{Authors' information}

Y.Q is a research fellow, and D.W. an assistant professor in The Brown Foundation Institute of Molecular Medicine for the prevention of Human Diseases, University of Texas Medical School at Houston, Houston, TX 77030 , USA. The major research goal of our project is to explore potential application of lung stem/progenitor cell types derived from iPSCS and ESCs for modeling pulmonary diseases and developing cell-based therapies for the treatment of severe lung diseases in animal models.

\section{Acknowledgements}

This work was supported by U.S. Public Health Service National Institutes Health Grants R21 HL102833-01 (D.W), University Texas Medical School Bridging Grant Program (D.W.), and the Welch Foundation Endowment Fund-7712 (D.W.).

Received: 11 April 2014 Accepted: 13 June 2014

Published: 17 June 2014

\section{References}

1. Song JJ, Ott HC: Bioartificial lung engineering. American journal of transplantation: official journal of the American Society of Transplantation and the American Society of Transplant Surgeons 2012, 12:283-288.

2. Taylor DO, Edwards LB, Boucek MM, Trulock EP, Keck BM, Hertz MI: The Registry of the International Society for Heart and Lung Transplantation: twenty-first official adult heart transplant report-2004. J Heart Lung Transplant 2004, 23:796-803.

3. Orens JB, Garrity ER Jr: General overview of lung transplantation and review of organ allocation. Proc Am Thorac Soc 2009, 6:13-19.

4. Kotton DN, Summer R, Fine A: Lung stem cells: new paradigms. Exp Hematol 2004, 32:340-343.

5. Loebinger MR, Janes SM: Stem cells for lung disease. Chest 2007, 132:279-285.

6. Wetsel RA, Wang D, Calame DG: Therapeutic potential of lung epithelial progenitor cells derived from embryonic and induced pluripotent stem cells. Annu Rev Med 2011, 62:95-105.
7. Uhal BD: Cell cycle kinetics in the alveolar epithelium. Am J Physio/ 1997, 272:L1031-L1045.

8. Hong KU, Reynolds SD, Watkins S, Fuchs E, Stripp BR: Basal cells are a multipotent progenitor capable of renewing the bronchial epithelium. Am J Pathol 2004, 164:577-588.

9. Boers JE, Ambergen AW, Thunnissen FB: Number and proliferation of clara cells in normal human airway epithelium. Am J Respir Crit Care Med 1999, 159:1585-1591.

10. Evans MJ, Cabral-Anderson L, Freeman G: Role of the Clara cell in renewal of the bronchiolar epithelium. Lab Invest 1978, 38:648-653.

11. Reddy R, Buckley S, Doerken M, Barsky L, Weinberg K, Anderson KD, Warburton D, Driscoll B: Isolation of a putative progenitor subpopulation of alveolar epithelial type 2 cells. Am J Physiol Lung Cell Mol Physiol 2004, 286:L658-L667.

12. Hong KU, Reynolds SD, Watkins S, Fuchs E, Stripp BR: In vivo differentiation potential of tracheal basal cells: evidence for multipotent and unipotent subpopulations. Am J Physiol Lung Cell Mol Physiol 2004, 286:L643-L649.

13. Rawlins EL, Okubo T, Que J, Xue Y, Clark C, Luo X, Hogan BL: Epithelial stem/progenitor cells in lung postnatal growth, maintenance, and repair. Cold Spring Harb Symp Quant Biol 2008, 73:291-295.

14. Engelhardt JF, Schlossberg H, Yankaskas JR, Dudus L: Progenitor cells of the adult human airway involved in submucosal gland development. Development 1995, 121:2031-2046.

15. Boers JE, Ambergen AW, Thunnissen FB: Number and proliferation of basal and parabasal cells in normal human airway epithelium. Am J Respir Crit Care Med 1998, 157:2000-2006.

16. Borthwick DW, Shahbazian M, Krantz QT, Dorin JR, Randell SH: Evidence for stem-cell niches in the tracheal epithelium. Am J Respir Cell Mol Biol 2001, 24:662-670.

17. Engelhardt JF: Stem cell niches in the mouse airway. Am J Respir Cell Mol Biol 2001, 24:649-652.

18. Hong KU, Reynolds SD, Giangreco A, Hurley CM, Stripp BR: Clara cell secretory protein-expressing cells of the airway neuroepithelial body microenvironment include a label-retaining subset and are critical for epithelial renewal after progenitor cell depletion. Am J Respir Cell Mol Biol 2001, 24:671-681.

19. Giangreco A, Reynolds SD, Stripp BR: Terminal bronchioles harbor a unique airway stem cell population that localizes to the bronchoalveolar duct junction. Am J Pathol 2002, 161:173-182.

20. Stripp BR, Maxson K, Mera R, Singh G: Plasticity of airway cell proliferation and gene expression after acute naphthalene injury. Am J Physiol 1995, 269:L791-L799.

21. Reynolds SD, Giangreco A, Power JH, Stripp BR: Neuroepithelial bodies of pulmonary airways serve as a reservoir of progenitor cells capable of epithelial regeneration. Am J Pathol 2000, 156:269-278.

22. Reynolds SD, Hong KU, Giangreco A, Mango GW, Guron C, Morimoto Y, Stripp BR: Conditional clara cell ablation reveals a self-renewing progenitor function of pulmonary neuroendocrine cells. Am J Physiol Lung Cell Mol Physiol 2000, 278:L1256-L1263.

23. Kim CF, Jackson EL, Woolfenden AE, Lawrence S, Babar I, Vogel S, Crowley D, Bronson RT, Jacks T: Identification of bronchioalveolar stem cells in normal lung and lung cancer. Cell 2005, 121:823-835.

24. Teisanu RM, Lagasse E, Whitesides JF, Stripp BR: Prospective isolation of bronchiolar stem cells based upon immunophenotypic and autofluorescence characteristics. Stem Cells 2009, 27:612-622.

25. Vacanti MP, Roy A, Cortiella J, Bonassar L, Vacanti CA: Identification and initial characterization of spore-like cells in adult mammals. J Cell Biochem 2001, 80:455-460.

26. Kajstura J, Rota M, Hall SR, Hosoda T, D'Amario D, Sanada F, Zheng H, Ogórek B, Rondon-Clavo C, Ferreira-Martins J, Matsuda A, Arranto C, Goichberg P, Giordano G, Haley KJ, Bardelli S, Rayatzadeh H, Liu X, Quaini F, Liao R, Leri A, Perrella MA, Loscalzo J, Anversa P: Evidence for human lung stem cells. N Engl J Med 2011, 364:1795-1806.

27. Wobus AM: Potential of embryonic stem cells. Mol Aspects Med 2001 22:149-164.

28. Odorico JS, Kaufman DS, Thomson JA: Multilineage differentiation from human embryonic stem cell lines. Stem Cells 2001, 19:193-204.

29. Wobus AM, Kaomei G, Shan J, Wellner MC, Rohwedel J, Ji G, Fleischmann B, Katus HA, Hescheler J, Franz WM: Retinoic acid accelerates embryonic stem cell-derived cardiac differentiation and enhances development of ventricular cardiomyocytes. J Mol Cell Cardiol 1997, 29:1525-1539. 
30. Muller M, Fleischmann BK, Selbert S, Ji GJ, Endl E, Middeler G, Müller OJ, Schlenke P, Frese S, Wobus AM, Hescheler J, Katus HA, Franz WM: Selection of ventricular-like cardiomyocytes from ES cells in vitro. Faseb J 2000, 14:2540-2548.

31. Okabe S, Forsberg-Nilsson K, Spiro AC, Segal M, McKay RD: Development of neuronal precursor cells and functional postmitotic neurons from embryonic stem cells in vitro. Mech Dev 1996, 59:89-102.

32. Brustle $\mathrm{O}$, Jones KN, Learish RD, Karram K, Choudhary K, Wiestler OD, Duncan ID, McKay RD: Embryonic stem cell-derived glial precursors: a source of myelinating transplants. Science 1999, 285:754-756.

33. Kramer J, Hegert C, Guan K, Wobus AM, Muller PK, Rohwedel J: Embryonic stem cell-derived chondrogenic differentiation in vitro: activation by BMP-2 and BMP-4. Mech Dev 2000, 92:193-205.

34. Buttery LD, Bourne S, Xynos JD, Wood H, Hughes FJ, Hughes SP, Episkopou $\checkmark$, Polak JM: Differentiation of osteoblasts and in vitro bone formation from murine embryonic stem cells. Tissue Eng 2001, 7:89-99.

35. Dani C, Smith AG, Dessolin S, Leroy P, Staccini L, Villageois P, Darimont C, Ailhaud G: Differentiation of embryonic stem cells into adipocytes in vitro. J Cell Sci 1997, 110(Pt 11):1279-1285.

36. Segev H, Fishman B, Ziskind A, Shulman M, Itskovitz-Eldor J: Differentiation of human embryonic stem cells into insulin-producing clusters. Stem Cells 2004, 22:265-274

37. Coraux C, Nawrocki-Raby B, Hinnrasky J, Kileztky C, Gaillard D, Dani C, Puchelle E: Embryonic stem cells generate airway epithelial tissue. Am J Respir Cell Mol Biol 2005, 32:87-92.

38. Van Vranken BE, Rippon HJ, Samadikuchaksaraei A, Trounson AO, Bishop AE: The differentiation of distal lung epithelium from embryonic stem cells. Current protocols in stem cell biology. In Chapter 1:Unit 1G; 2007.

39. Ali NN, Edgar AJ, Samadikuchaksaraei A, Timson CM, Romanska HM, Polak JM, Bishop AE: Derivation of type II alveolar epithelial cells from murine embryonic stem cells. Tissue Eng 2002, 8:541-550.

40. Samadikuchaksaraei A, Cohen S, Isaac K, Rippon HJ, Polak JM, Bielby RC, Bishop AE: Derivation of distal airway epithelium from human embryonic stem cells. Tissue Eng 2006, 12:867-875.

41. Van Vranken BE, Romanska HM, Polak JM, Rippon HJ, Shannon JM, Bishop AE: Coculture of embryonic stem cells with pulmonary mesenchyme: a microenvironment that promotes differentiation of pulmonary epithelium. Tissue Eng 2005, 11:1177-1187.

42. Rippon HJ, Polak JM, Qin M, Bishop AE: Derivation of distal lung epithelial progenitors from murine embryonic stem cells using a novel three-step differentiation protocol. Stem Cells 2006, 24:1389-1398.

43. Roszell B, Mondrinos MJ, Seaton A, Simons DM, Koutzaki SH, Fong GH, Lelkes PI, Finck CM: Efficient derivation of alveolar type II cells from embryonic stem cells for in vivo application. Tissue Eng Part A 2009, 15:3351-3365

44. Wang D, Haviland DL, Burns AR, Zsigmond E, Wetsel RA: A pure population of lung alveolar epithelial type II cells derived from human embryonic stem cells. Proc Natl Acad Sci U S A 2007, 104:4449-4454.

45. Wang D, Morales JE, Calame DG, Alcorn JL, Wetsel RA: Transplantation of human embryonic stem cell-derived alveolar epithelial type II cells abrogates acute lung injury in mice. Mol Ther 2010, 18:625-634.

46. Moore BB, Hogaboam CM: Murine models of pulmonary fibrosis. Am J Physiol Lung Cell Mol Physiol 2008, 294:L152-L160.

47. Chua F, Gauldie J, Laurent GJ: Pulmonary fibrosis: searching for model answers. Am J Respir Cell Mol Biol 2005, 33:9-13.

48. Sun H, Quan Y, Yan Q, Peng X, Mao Z, Wetsel RA, Wang D: Isolation and characterization of alveolar epithelial type II cells derived from mouse embryonic stem cells. Tissue Eng Part C Methods 2014, 20:464-472.

49. Takahashi K, Yamanaka S: Induction of pluripotent stem cells from mouse embryonic and adult fibroblast cultures by defined factors. Cell 2006, 126:663-676.

50. Yamanaka S: Takahashi K [Induction of pluripotent stem cells from mouse fibroblast cultures]. Tanpakushitsu Kakusan Koso 2006, 51:2346-2351.

51. Yu J, Vodyanik MA, Smuga-Otto K, Antosiewicz-Bourget J, Frane JL, Tian S, Nie J, Jonsdottir GA, Ruotti V, Stewart R, Slukvin II, Thomson JA: Induced pluripotent stem cell lines derived from human somatic cells. Science 2007, 318:1917-1920.

52. Stadtfeld M, Nagaya M, Utikal J, Weir G, Hochedlinger K: Induced pluripotent stem cells generated without viral integration. Science 2008, 322:945-949.
53. Fusaki N, Ban H, Nishiyama A, Saeki K, Hasegawa M: Efficient induction of transgene-free human pluripotent stem cells using a vector based on Sendai virus, an RNA virus that does not integrate into the host genome. Proc Jpn Acad Ser B Phys Biol Sci 2009, 85:348-362.

54. Jia F, Wilson KD, Sun N, Gupta DM, Huang M, Li Z, Panetta NJ, Chen ZY, Robbins RC, Kay MA, Longaker MT, Wu JC: A nonviral minicircle vector for deriving human iPS cells. Nat Methods 2010, 7:197-199.

55. Yu J, Hu K, Smuga-Otto K, Tian S, Stewart R, Slukvin II, Thomson JA: Human induced pluripotent stem cells free of vector and transgene sequences. Science 2009, 324:797-801.

56. Woltjen $K$, Michael IP, Mohseni $P$, Desai R, Mileikovsky $M$, Hämäläinen $R$, Cowling R, Wang W, Liu P, Gertsenstein M, Kaji K, Sung H-K, Nagy A: piggyBac transposition reprograms fibroblasts to induced pluripotent stem cells. Nature 2009, 458:766-770.

57. Kim D, Kim CH, Moon Jl, Chung YG, Chang MY, Han BS, Ko S, Yang E, Cha KY, Lanza R, Kim KS: Generation of human induced pluripotent stem cells by direct delivery of reprogramming proteins. Cell Stem Cell 2009, 4:472-476.

58. Warren L, Manos PD, Ahfeldt T, Loh YH, Li H, Lau F, Ebina W, Mandal PK, Smith ZD, Meissner A, Daley GQ, Brack AS, Collins JJ, Cowan C, Schlaeger TM, Rossi DJ: Highly efficient reprogramming to pluripotency and directed differentiation of human cells with synthetic modified mRNA. Cell Stem Cell 2010, 7:618-630.

59. Miyoshi N, Ishii H, Nagano H, Haraguchi N, Dewi DL, Kano Y, Nishikawa S, Tanemura M, Mimori K, Tanaka F, Saito T, Nishimura J, Takemasa I, Mizushima T, Ikeda M, Yamamoto H, Sekimoto M, Doki Y, Mori M: Reprogramming of mouse and human cells to pluripotency using mature microRNAs. Cell Stem Cell 2011, 8:633-638.

60. Wang S, Bates J, Li X, Schanz S, Chandler-Militello D, Levine C, Maherali N, Studer L, Hochedlinger K, Windrem M, Goldman SA: Human iPSC-derived oligodendrocyte progenitor cells can myelinate and rescue a mouse model of congenital hypomyelination. Cell Stem Cell 2013, 12:252-264.

61. Sareen D, Gowing G, Sahabian A, Staggenborg K, Paradis R, Avalos P, Latter J, Ornelas L, Garcia L, Svendsen CN: Human induced pluripotent stem cells are a novel source of neural progenitor cells (iNPCs) that migrate and integrate in the rodent spinal cord. J Comp Neurol 2014.

62. Abdelalim EM, Bonnefond A, Bennaceur-Griscelli A, Froguel P: Pluripotent stem cells as a potential tool for disease modelling and cell therapy in diabetes. Stem Cell Rev 2014, 10:327-337.

63. Doi D, Samata B, Katsukawa M, Kikuchi T, Morizane A, Ono Y, Sekiguchi K, Nakagawa M, Parmar M, Takahashi J: Isolation of human induced pluripotent stem cell-derived dopaminergic progenitors by cell sorting for successful transplantation. Stem cell reports 2014, 2:337-350.

64. Somers A, Jean JC, Sommer CA, Omari A, Ford CC, Mills JA, Ying L, Sommer $A G$, Jean JM, Smith BW, Lafyatis R, Demierre MF, Weiss DJ, French DL, Gadue P, Murphy GJ, Mostoslavsky G, Kotton DN: Generation of transgene-free lung disease-specific human induced pluripotent stem cells using a single excisable lentiviral stem cell cassette. Stem Cells 2010, 28:1728-1740.

65. Yan Q, Quan Y, Sun H, Peng X, Zou Z, Alcorn JL, Wetsel RA, Wang D: A site-specific genetic modification for induction of pluripotency and subsequent isolation of derived lung alveolar epithelial type II cells. Stem Cells 2014, 32:402-413.

66. Ott HC, Matthiesen TS, Goh SK, Black LD, Kren SM, Netoff TI, Taylor DA: Perfusion-decellularized matrix: using nature's platform to engineer a bioartificial heart. Nat Med 2008, 14:213-221.

67. Uygun BE, Soto-Gutierrez A, Yagi H, Izamis ML, Guzzardi MA, Shulman C, Milwid J, Kobayashi N, Tilles A, Berthiaume F, Hertl M, Nahmias Y, Yarmush ML, Uygun K: Organ reengineering through development of a transplantable recellularized liver graft using decellularized liver matrix. Nat Med 2010, 16:814-820.

68. Buffington DA, Westover AJ, Johnston KA, Humes HD: The bioartificial kidney. Translational research : the journal of laboratory and clinical medicine 2014, 163:342-351.

69. Chen P, Marsilio E, Goldstein RH, Yannas IV, Spector M: Formation of lung alveolar-like structures in collagen-glycosaminoglycan scaffolds in vitro. Tissue Eng 2005, 11:1436-1448.

70. Cortiella J, Nichols JE, Kojima K, Bonassar LJ, Dargon P, Roy AK, Vacant MP, Niles JA, Vacanti CA: Tissue-engineered lung: an in vivo and in vitro comparison of polyglycolic acid and pluronic F-127 hydrogel/somatic lung progenitor cell constructs to support tissue growth. Tissue Eng 2006, 12:1213-1225. 
71. Mondrinos MJ, Koutzaki S, Jiwanmall E, Li M, Dechadarevian JP, Lelkes PI, Finck CM: Engineering three-dimensional pulmonary tissue constructs. Tissue Eng 2006, 12:717-728.

72. Mondrinos MJ, Koutzaki SH, Poblete HM, Crisanti MC, Lelkes PI, Finck CM: In vivo pulmonary tissue engineering: contribution of donor-derived endothelial cells to construct vascularization. Tissue Eng Part A 2008, 14:361-368

73. Andrade CF, Wong AP, Waddell TK, Keshavjee S, Liu M: Cell-based tissue engineering for lung regeneration. Am J Physiol Lung Cell Mol Physiol 2007, 292:L510-L518.

74. Macchiarini P, Jungebluth P, Go T, Asnaghi MA, Rees LE, Cogan TA, Dodson A, Martorell J, Bellini S, Parnigotto PP, Dickinson SC, Hollander AP, Mantero $\mathrm{S}$, Conconi MT, Birchall MA: Clinical transplantation of a tissue-engineered airway. Lancet 2008, 372:2023-2030

75. Macchiarini P, Walles T, Biancosino C, Mertsching H: First human transplantation of a bioengineered airway tissue. J Thorac Cardiovasc Surg 2004, 128:638-641

76. Gonfiotti A, Jaus MO, Barale D, Baiguera S, Comin C, Lavorini F, Fontana G, Sibila O, Rombolà G, Jungebluth P, Macchiarini P: The first tissue-engineered airway transplantation: 5-year follow-up results. Lancet 2014, 383:238-244.

77. Petersen TH, Calle EA, Zhao L, Lee EJ, Gui L, Raredon MB, Gavrilov K, Yi T, Zhuang ZW, Breuer C, Herzog E, Niklason LE: Tissue-engineered lungs for in vivo implantation. Science 2010, 329:538-541.

78. Ott HC, Clippinger B, Conrad C, Schuetz C, Pomerantseva I, Ikonomou L, Kotton D, Vacanti JP: Regeneration and orthotopic transplantation of a bioartificial lung. Nat Med 2010, 16:927-933.

79. Zhao T, Zhang ZN, Rong Z, Xu Y: Immunogenicity of induced pluripotent stem cells. Nature 2011, 474:212-215.

doi:10.1186/2001-1326-3-15

Cite this article as: Quan and Wang: Clinical potentials of human pluripotent stem cells in lung diseases. Clinical and Translational Medicine 2014 3:15.

\section{Submit your manuscript to a SpringerOpen ${ }^{\circ}$ journal and benefit from:}

- Convenient online submission

- Rigorous peer review

- Immediate publication on acceptance

- Open access: articles freely available online

- High visibility within the field

- Retaining the copyright to your article 